\title{
Pretreatment of Seawater Using Forward Osmosis for Multistage Flash Desalination
}

\author{
Alaa H. Hawari ${ }^{a, *}$, Mhd. Hafez Ammar ${ }^{\mathrm{a}}$, Ahmed T. Yasir ${ }^{\mathrm{a}}$, Syed Zaidi ${ }^{\mathrm{b}}$, Ali Altaee \\ aDepartment of Civil and Architectural Engineering, Qatar University, P.O. Box 2713, Doha, Qatar. \\ ${ }^{\mathrm{b}}$ Centre for Advanced Materials, Qatar University, P.O. Box 2713, Doha, Qatar. \\ ${ }^{\mathrm{c} S}$ School of Civil and Environmental Engineering, University of Technology in Sydney, 15 Broadway, Ultimo, NSW \\ 2007, Australia. \\ *Corresponding authors
}

\begin{abstract}
Pretreatment of seawater using Forward Osmosis (FO) before a Multistage Flash (MSF) desalination plant could enhance the performance of the thermal desalination process. In this study, brine is used as the draw solution while the feed solution is seawater. The impact of the flow rate of the feed solution and the draw solution on the membrane flux was studied. In addition, the impact of pretreatment of feed solution by a sand filter on the membrane flux was studied. The pretreatment of the feed solution (i.e. seawater) had minimal impact on the membrane flux. A membrane flux of 14.2 LPM and 13.4 LPM was obtained with non-treated seawater as feed solution and treated seawater as feed solution, respectively. The recovery rate was $26 \%$ and $24 \%$ for the non-treated seawater and treated seawater, respectively.
\end{abstract}

Keywords: Forward Osmosis (FO); Multistage flash (MSF); Pretreatment; Membrane flux; Sand filter.

\section{Introduction}

Multistage flash (MSF) and multi effect distillation (MED) are the main thermal desalination technologies that have successfully met water demands in arid areas. Generally, the seawater feed to MSF and MED does not require any pre-treatment. The top brine temperature (TBT) is the highest operating temperature in the desalination processes which is $65^{\circ} \mathrm{C}$ and $110^{\circ} \mathrm{C}$ for MED and MSF, respectively [1-3]. These technologies suffers from loss of efficiency due to scaling on the inner surface of heat transferring equipments. For long, the problem with scaling has been tackled by adding anti-scalants and regular maintenance of the equipment. However, these anti-scaling strategies are not sufficient as scale build up over time cannot be avoided [2,47]. In recent years, feed pretreatment methods are being investigated with the aim of reducing the concentration of scale causing ions [8,9]. Hassan et al. proposed pretreatment of feed to MSF using nano-filtration [9]. The Study showed the usefulness of nano-filters to decrease the concentration of divalent ions that enables the MSF process to run at an elevated TBT of $130^{\circ} \mathrm{C}$. When operated at TBT of $130{ }^{\circ} \mathrm{C}$, the gained output ratio (GOP) of the desalination plant can reach as high as 13 [11-13]. However, nano-filtration is costly and not deemed feasible for water production at lower 
operating cost. For a $65 \%$ recovery rate in $\mathrm{NF}, 1 \mathrm{kWh}$ energy is required per $\mathrm{m}^{3}$ water. This extra energy cost increases the cost of water and makes NF unfeasible [14,15].

Forward Osmosis is a process that uses the osmotic pressure gradient between feed solution (FS) and draw solution (DS) as the driving force instead of hydraulic pressure [16,17]. Thus, the operating cost of FO is expected to be lower than any other membrane process. Using $2 \mathrm{ppb} \mathrm{NaCl}$ solution as feed solution, a synthetic seawater was pretreated before using in a reverse osmosis (RO) process. Due to the pretreatment, the rejection rate in the RO process reached 99.99\% [15]. A simulation study my Altaee et al. showed that, major scaling ions in MED/MSF can be removed by pretreatment by FO [16]. Altaee et al. used brine reject as draw solution and seawater as feed solution in their simulation study [16]. In the simulation, $32 \%$ recovery rate was achievable with $62 \%$ reduction in $\mathrm{Ca}^{2+}, \mathrm{Mg}^{2+}$ and $\mathrm{SO}_{4}{ }^{2-}$ ions[16]. It was expected that, for seawater with 45000 ppm salt concentration, the water flux is between $4 \mathrm{~L} / \mathrm{m}^{2} . h$ to $9.6 \mathrm{~L} / \mathrm{m}^{2} . h$ depending on the recovery rate in the FO process. For seawater with same salinity, $16 \%$ flux was recoverable in FO and the concentration of divalent ions was reduced by $13 \%$ [14]. Increasing the recovery rate to $32 \%$ reduced the concentration of divalent ions by $23 \%$ [14]. In another study by Thabit et al. an experimental study was performed to study the feasibility of using FO as a pre-treatment process for MSF [17]. Real seawater was used as the feed solution and real brine reject was used as the draw solution in the FO process [17]. An average membrane flux of $16.9 \mathrm{~L} / \mathrm{m}^{2} . \mathrm{h}$ was obtained at a flow rate of 2.0 LPM for the draw solution and the feed solution. In addition, it was found that the FO process was able to reject the scale forming ions.

In this study FO is proposed as a pretreatment process for MSF where brine is used as the draw solution and seawater is used as the feed solution. However, the impact of the pretreatment of seawater by a sand filter before the FO process on the membrane flux, recovery rate and reverse solute flux is assessed. 
2ND International Conference on Applied Research in

ENGINEERING, SCIENCE AND TECHNOLOGY

5 - 7 JUNE, 2019

BRUSSELS, BELGIUM

\section{Methodology}

2.1 raw and Feed solutions characteristics

In the FO process, the draw solution (DS) was a brine reject (BR) collected from an MSF desalination plant in Qatar, while real seawater (SW) collected from a bay in Qatar was the feed solution (FS). The properties of the DS and FS are illustrated in Table 1.

Table 1. Characteristics of brine reject of MSF and seawater [17]

\begin{tabular}{llll}
\hline & FS (SW) & DS (BR) & Method \\
\hline $\mathbf{C r}(\mathbf{p p m})$ & 22183.7 & 35377.9 & $\begin{array}{l}\text { APHA 4110 DETERMINATION OF ANIONS BY ION } \\
\text { CHROMATOGRAPHY }\end{array}$ \\
$\mathbf{N a}^{+}$(ppm) & 12952.6 & 20993.4 & $\begin{array}{l}\text { APHA 3120 METALS BY PLASMA EMISSION } \\
\text { SPECTROSCOPY }\end{array}$ \\
$\begin{array}{l}\text { TDS (ppm) } \\
\text { Conductivity }\end{array}$ & 63474 & 81492 & APHA 2540 C. Total Dissolved Solids Dried at $180^{\circ} \mathrm{C}$ \\
$(\boldsymbol{\mu s} / \mathbf{c m})$ & 93650 & APHA 2510 B. Conductivity \\
$\mathbf{p H}$ & 8.40 & 9.07 & APHA 4500-H+B. Electrometric Method \\
\hline
\end{tabular}

2.2 Sand filter

The schematic diagram of the sand filter used for pre-treatment of seawater can be seen in Figure 1. The seawater enters the sand filter from the top and exits from the bottom after the filtration process. The sand bed is regenerated by backwashing the column using tab water. 
2ND International Conference on Applied Research in

ENGINEERING, SCIENCE AND TECHNOLOGY

5 - 7 JUNE, 2019

BRUSSELS, BELGIUM

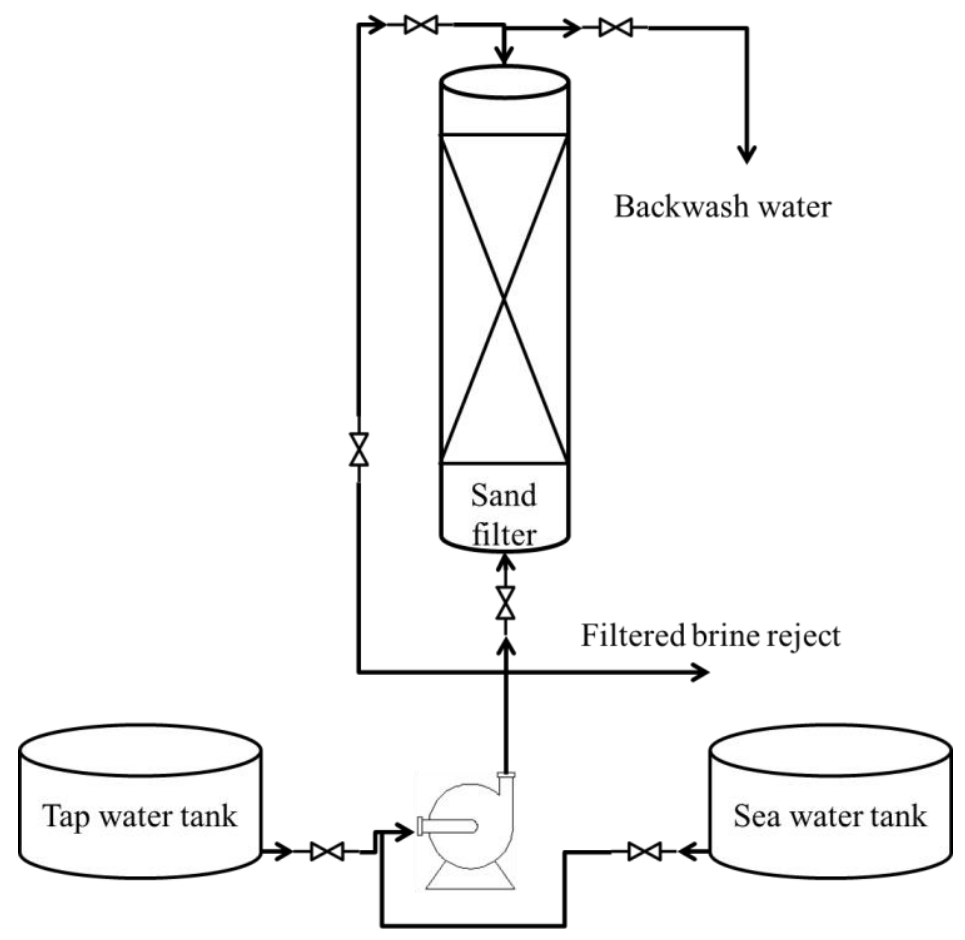

Figure 1. Schematic diagram of the sand filtration process.

\subsection{FO membrane}

A flat sheet Thin Film Composite (TFC) FO membrane procured by HTI (USA) was used in this study. The membrane can endure temperatures up to $40{ }^{\circ} \mathrm{C}$ and has a rejection rate of $90 \%$ for $\mathrm{NaCl}$. In order to remove any impurities from the surface of the membrane, the membrane was washed for 30 minutes using distilled water. A Sepa CF high fouling spacer with $1 \mathrm{~mm}$ thickness and dimensions of $8 \times 3.5 \mathrm{~cm}$ was positioned on the support side of the FO membrane.

\subsection{FO Bench-scale unit}

The Forward Osmosis cell used in this study was purchased from Sterlitech (CF042D). The FO cell has dimensions of $12.7 \mathrm{~cm}$ length, $10 \mathrm{~cm}$ width and $8.3 \mathrm{~cm}$ depth. The active membrane area inside the cell is $42 \mathrm{~cm}^{2}$. Other components of the bench-scale setup and their functions are listed below:

1. Two stainless steel tank that supplies FS and DS. Both of the tanks can hold 9L solution.

2. Two flow meters provided by Blue-white industries Ltd. The range of the flowmeters is up to 4 LPM.

3. Two mount gear pumps with maximum achieve able flow rate of 3.2 LPM was used. The pumps contained Console Drive 115 VPEEK Gears/PTFE seals. 
2ND International Conference on Applied Research in

ENGINEERING, SCIENCE AND TECHNOLOGY

5 - 7 JUNE, 2019

BRUSSELS, BELGIUM

4. Two PEM type pressure gauges from Winters Company. The range of measured pressure ranges between 0-3 bar.

5. The conductivity, salinity and TDS concentration of the FS and DS were measured by OAKTON PCD650 multi meter.

6. The weight of the water was measured by and recorded by Ohaus Ranger ${ }^{\mathrm{TM}}$ benchscale balance connected to a computer.

The flux of water was calculated using the following Equation:

$$
J_{w}(L M H)=1000 \times \frac{\Delta W}{A t \rho}=\frac{1000\left(W_{f}-W_{i}\right)}{A t \rho}
$$

Here, $\mathrm{W}_{\mathrm{f}}$ is the final weight of the draw solution measured after 1450 minutes of operation, $\mathrm{W}_{\mathrm{i}}$ is the initial weight of draw solution $(\mathrm{kg}), \mathrm{A}$ is the area of the membrane $\left(\mathrm{m}^{2}\right), t$ is the running time of the experiment (minutes) and $\rho$ is density of water $\left(\mathrm{kg} / \mathrm{m}^{3}\right)$. The system was run as a closed system were the feed solution and the draw solution were recycled. Figure 2 shows a schematic diagram of the used FO system.

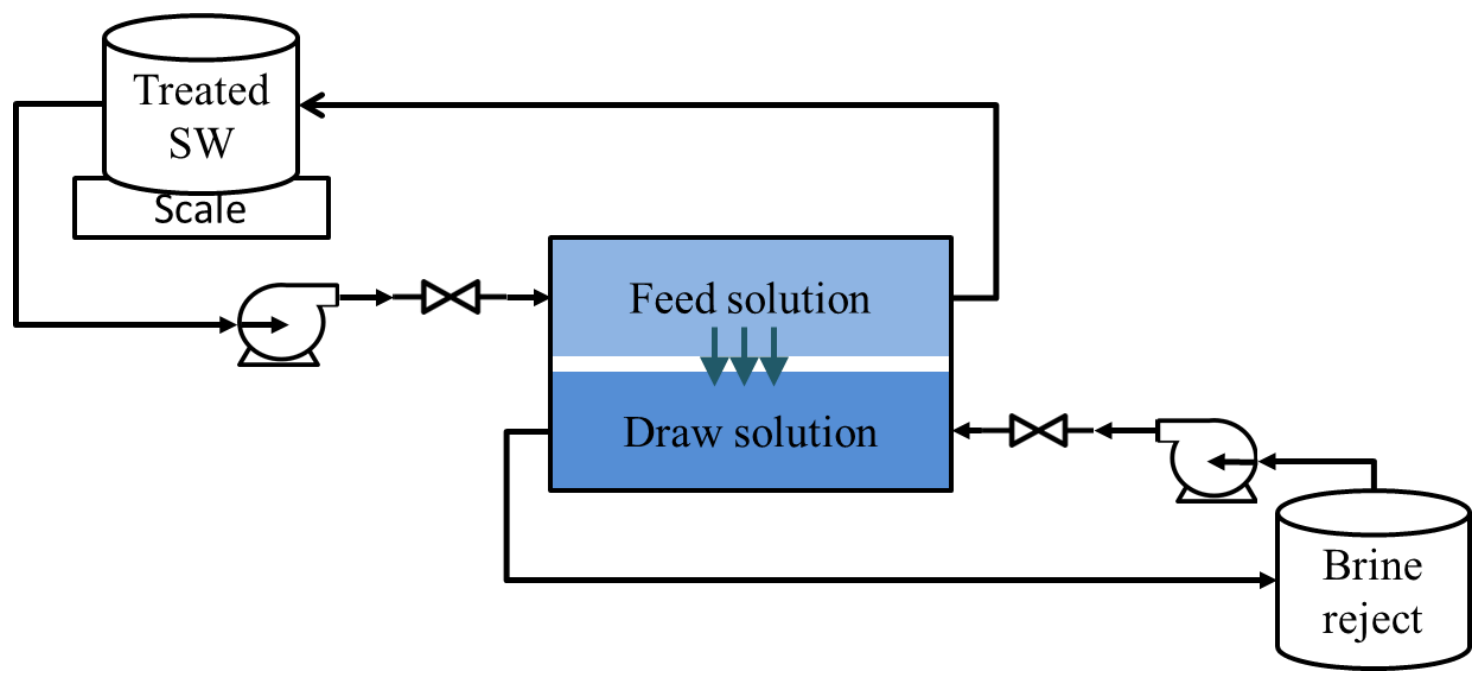

Figure 2. A schematic diagram of the used FO system.

\subsection{Experimental procedure}

The seawater was treated using a sand filter. The seawater was pumped through the sand filter with a flow rate of 5 LPM. The treated seawater was transferred to the feed solution tank in the FO process. The FO process was operated for 1450 minutes with a recycled mode. The flowrate of both DS and FS was kept constant at 2.0 LPM. The impact of the pretreament of the FS on the performance of the FO process was studied by coparing average membrane flux, recovery rate and reverse solute flux. After each run, the system was washed with distilled water for 30 minutes. The flow of FS and DS was set incounter current mode. The process flow diagramfor the combined process can be seen in Figure 3. 


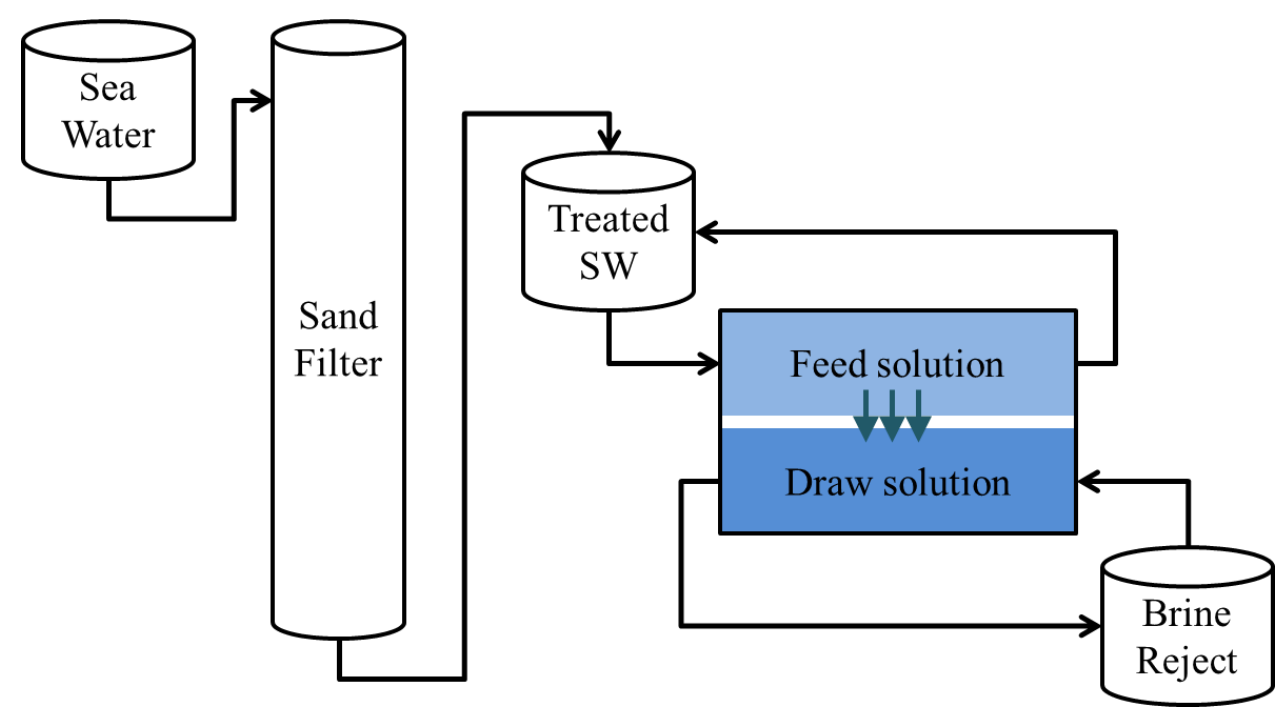

Figure 3. Process flow diagram of FO process assisted by sand filtration.

\section{Results and Discussion}

The effect of pre-treatment on the membrane flux in the forward osmosis (FO) process was investigated by comparing fluxes of treated and non-treated feed solution. The flow rate of draw solution (DS) and feed solution (FS) was kept constant at 2.0 LPM. The FO process was run for 1450 minutes. Figure 4 shows the change of membrane flux with time for pre-treated and non-treated FS. Initially the membrane flux with non-treated FS was $42.8 \mathrm{LMH}$. As time progressed, the membrane flux reduced and reached an average of 14.2 LMH for the entire duration of operation. When, pre-treated FS was used in the FO process, the initial membrane flux was 78.6 LMH. With time, the flux reduced and reached an average of 13.4 LMH for the entire treatment period. Although, the initial flux with pre-treated FS was higher than the initial flux of the non-treated FS, the average flux for both runs was almost equal showing no high impact for the pretreatment process. This could be because sand filter will only remove colloidal 
2ND International Conference on Applied Research in

ENGINEERING, SCIENCE AND TECHNOLOGY

5 - 7 JUNE, 2019

BRUSSELS, BELGIUM

and suspended particles from the feed solution. Hence, the driving force which is the osmotic gradient does not change with the treatment of the FS.

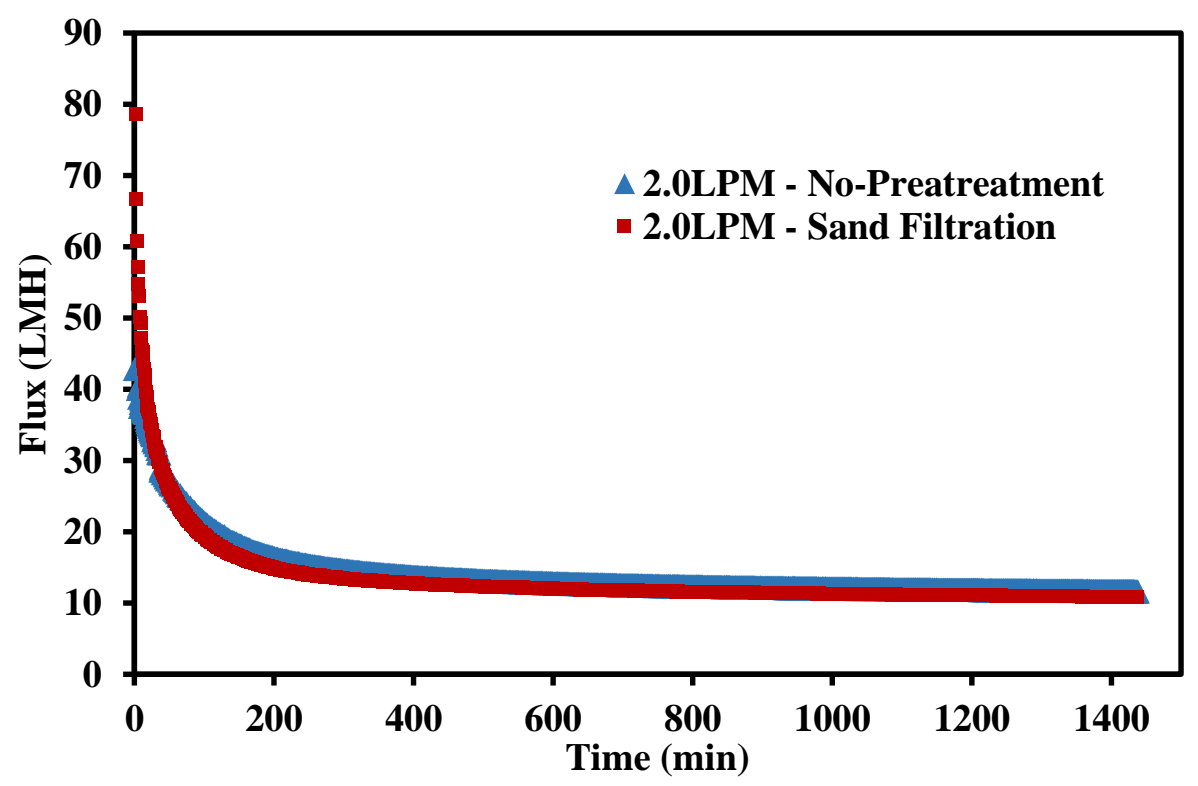

Figure 4. Effect of pre-treatment on membrane flux.

Figure 5 shows the recovery rate in the FO process with treated and untreated FS. The recovery rate was calculated as [19]:

$$
\% \mathrm{R}=\frac{\mathrm{V}_{p}}{\mathrm{~V}_{\mathrm{F}}} \times 100 \%
$$

Here, $V_{p}$ is the permeate volume $(\mathrm{L})$ and $\mathrm{V}_{\mathrm{F}}$ is the feed solution volume $(\mathrm{L})$. The recovery rate for the FO process with non-treated FS was $26 \%$ and showed an almost similar recovery rate of $24 \%$ when pre-treated FS was used in the FO process. 
2ND International Conference on Applied Research in

ENGINEERING, SCIENCE AND TECHNOLOGY

5 - 7 JUNE, 2019

BRUSSELS, BELGIUM

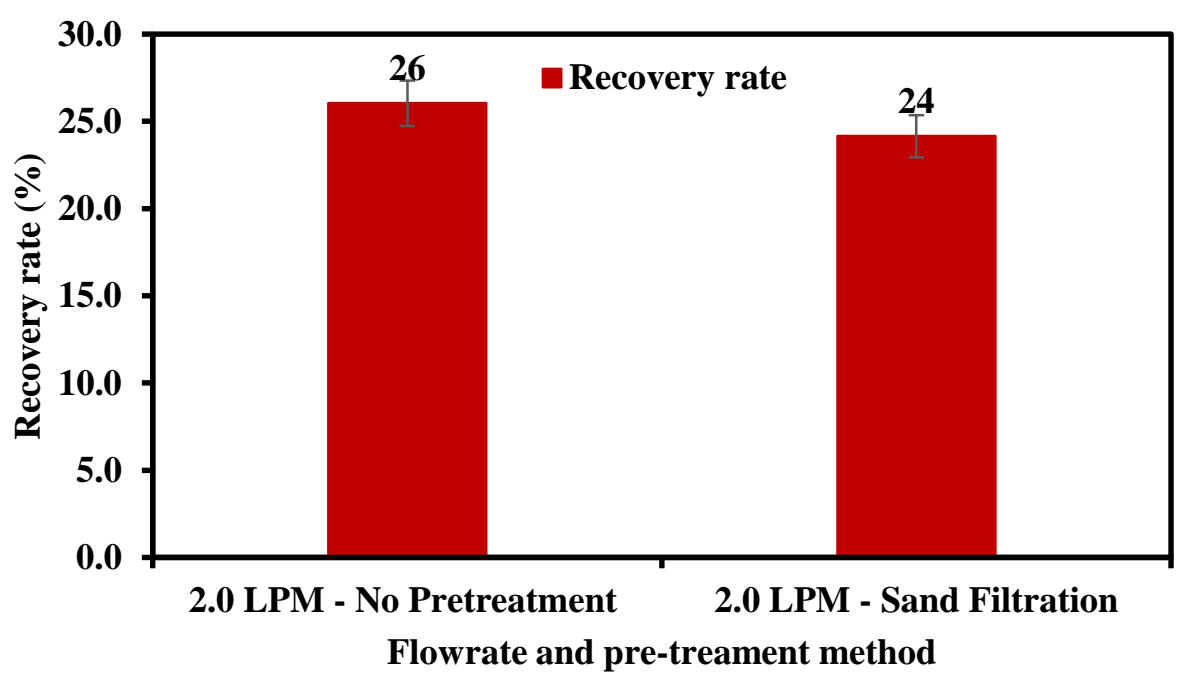

Figure 5. Permeate flux and recovery rate for pre-treated and non-treated draw solution.

Another parameter that indicates the performance of FO process is reverse solute flux. Reverse solute flux (RSF) is the back diffusion of the draw solute across the FO membrane to the feed solution. RSF must be considered in the FO studies because it has the potential to contaminate the feed solution. Figure 6 shows the RSF for the FO process with pretreated and non-treated FS. For the non-treated FS, the RSF is found to be $282 \mathrm{mg} / \mathrm{m}^{2} . \mathrm{h}$. Treating the FS with a sand filter, reduced the RSF to $235 \mathrm{gm} / \mathrm{m}^{2} . \mathrm{h}$. 
2ND International Conference on Applied Research in

ENGINEERING, SCIENCE AND TECHNOLOGY

5 - 7 JUNE, 2019

BRUSSELS, BELGIUM

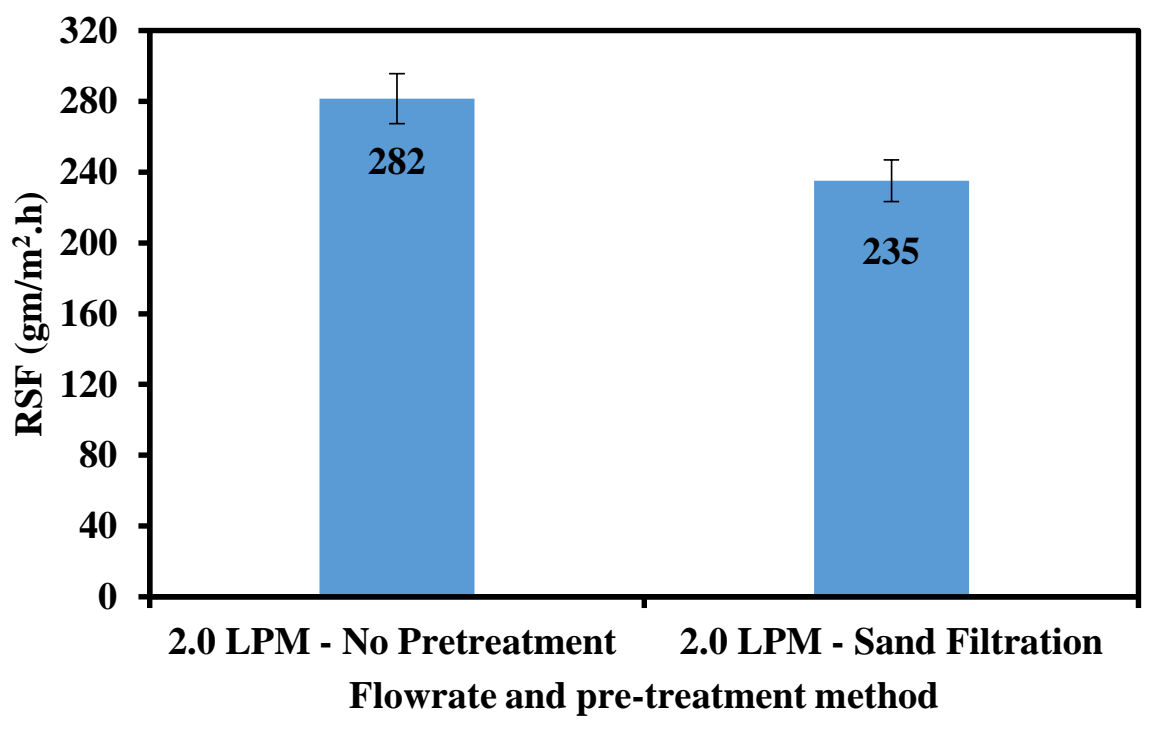

Figure 6. Effect of pre-treatment on reverse solute flux.

\section{Conclusion}

In this paper, effect of pre-treatment of FS on the performance of FO process has been studied. The feed solution was treated and untreated seawater while the draw solution was brine reject. The flow rate of both DS and FS were set at 2.0 LPM. It was found that the treatment of seawater (i.e. feed solution) had minimal effect on the membrane flux in the FO process. This could be due to the fact that sand filter will only remove colloidal and suspended particles from the feed solution. Hence, the driving force which is the osmotic gradient does not change with the treatment of the FS. Although, sand filtration as pre-treatment process did not showed any enhancement on the performance of the FO process, other pre-treatment processes should be investigated; e.g. Nano and Ultra filtration.

\section{Acknowledgments}

This research is made possible by NPRP award (NPRP10-0117-170176) from Qatar National Research Fund (QNRF). The statements made herein are solely the responsibility of the authors. In addition, the authors wish to thank Qatar Foundation for the financial support provided to one of the co-authors through a graduate sponsorship research award (GSRA4-2-0402-17013).

\section{References}

[1] Budhiraja P, Fares AA. Studies of scale formation and optimization of antiscalant dosing in multi-effect thermal desalination units. Desalination. 2008;220(1-3):313-25. 
2ND International Conference on Applied Research in

ENGINEERING, SCIENCE AND TECHNOLOGY

5 - 7 JUNE, 2019

BRUSSELS, BELGIUM

[2] Ghani S, Al-Deffeeri NS. Impacts of different antiscalant dosing rates and their thermal performance in Multi Stage Flash (MSF) distiller in Kuwait. Desalination [Internet]. 2010;250(1):463-72. Available from: http://dx.doi.org/10.1016/j.desal.2009.09.077

[3] El Din AMS, Mohammed RA. Brine and scale chemistry in MSF distillers. Desalination. 1994; 99(1):73-111.

[4] Tijing LD, Woo YC, Choi JS, Lee S, Kim SH, Shon HK. Fouling and its control in membrane distillation-A review. J Memb Sci [Internet]. 2015;475:215-44. Available from: http://dx.doi.org/10.1016/j.memsci.2014.09.042

[5] Amjad Z. Calcium sulfate dihydrate (gypsum) scale formation on heat exchanger surfaces: The influence of scale inhibitors. J Colloid Interface Sci. 1988;123(2):523-36.

[6] Lyster E, Kim M man, Au J, Cohen Y. A method for evaluating antiscalant retardation of crystal nucleation and growth on RO membranes. J Memb Sci [Internet]. 2010;364(12):122-31. Available from: http://dx.doi.org/10.1016/j.memsci.2010.08.020

[7] Warsinger DM, Swaminathan J, Guillen-Burrieza E, Arafat HA, Lienhard V JH. Scaling and fouling in membrane distillation for desalination applications: A review. Desalination [Internet]. 2015;356:294-313. Available from: http://dx.doi.org/10.1016/j.desal.2014.06.031

[8] Nicoll PG. Forward osmosis as a pre-treatment to reverse osmosis. Int Desalin Assoc World Congr Desalin Water Reuse 2013 [Internet]. 2013;1-21. Available from: http://www.modernwater.com/assets/downloads/Papers/Forward Osmosis as a Pretreatment to Reverse Osmosis.pdf

[9] Hassan AM, Al-Sofi MAK, Al-Amoudi AS, Jamaluddin ATM, Farooque AM, Rowaili A, et al. A new approach to membrane and thermal seawater desalination processes using nanofiltration membranes (Part 1). Desalination. 1998;118(1-3):35-51.

[10] Abdel Nasser Mabrouk, Hassan Fath MD and HA. Techno-Economics of Hybrid NF / FO with Thermal Desalination Plants. World's largest Science, Technology \& Medicine Open Access book publisher. 2015 p.

[11] Eriksson P, Kyburz M, Pergande W. NF membrane characteristics and evaluation for sea water processing applications. Desalination. 2005;184(1-3):281-94.

[12] Mezher T, Fath H, Abbas Z, Khaled A. Techno-economic assessment and environmental impacts of desalination technologies. Desalination. 2011;266(1-3):263-73.

[13] Altaee A. Forward Osmosis : Potential use in Desalination and Water Reuse. J Membr Sep Technol. 2012;1(Md):79-93.

[14] Altaee A, Mabrouk A, Bourouni K, Palenzuela P. Forward osmosis pretreatment of seawater to thermal desalination: High temperature FO-MSF/MED hybrid system. Desalination [Internet]. 2014;339(1):18-25. Available from: http://dx.doi.org/10.1016/j.desal.2014.02.006

[15] Petty JD, Huckins JN, David A. (12) Patent Application Publication (10) Pub . No .: US 2002/0187020 A1. 2002;1(19).

[16] Altaee A, Mabrouk A, Bourouni K. A novel Forward osmosis membrane pretreatment of seawater for thermal desalination processes. Desalination [Internet]. 2013;326:19-29. 
2ND International Conference on Applied Research in

\section{ENGINEERING, SCIENCE AND TECHNOLOGY}

BRUSSELS, BELGIUM

Available from: http://dx.doi.org/10.1016/j.desal.2013.07.008

[17] M. S Thabit, A. Al Hawari, M. Hafez Ammar, J. Zaidi, G. Zaragoza, and A. Altaee, Evaluation of forward osmosis as a pretreatment process for multi stage flash seawater desalination. 2019, p. 22.

[18] Hassan AM. Review of Development of the New Nf-Seawater Desalination Process From Pilot Plant To. Engineering. 2002;2(December):14-7.

[19] Xu Y, Peng X, Tang CY, Fu QS, Nie S. Effect of draw solution concentration and operating conditions on forward osmosis and pressure retarded osmosis performance in a spiral wound module. J Memb Sci. 2010;348(1-2):298-309. 